\title{
Chemical composition and nutritional value of different seaweeds from the west Algerian coast
}

Hanane Oucif ${ }^{1,2}$, Miloud Benaissa ${ }^{2}$, Smail Ali Mehidi ${ }^{1}$, Ricardo Prego ${ }^{3}$, Santiago P. Aubourg, ${ }^{4, *}$ and Sidi-Mohamed El-Amine Abi-Ayad ${ }^{1}$

${ }^{1}$ Laboratory of Aquaculture and Bioremediation, Department of Biotechnology, Faculty of Natural and Life Sciences (Campus I.G.M.O.), University Oran 1 Ahmed Ben Bella, Oran (Algeria). ORCID IDs: https://orcid.org/0000-0003-2620-0361 (H Oucif), https://orcid.org/0000-0003-2793-0585 (S Ali Mehidi) and https://orcid.org/0000-0001-5904-8752 (S-M Abi-Ayad)

${ }^{2}$ Department of Biology, Institute of Exact Sciences and Natural and Life Sciences, University Centre Ahmed Zabana of Relizane, Relizane (Algeria). ORCID ID: https://orcid.org/0000-0002-8147-2055 (M Benaissa)

${ }^{3}$ Department of Oceanography, Instituto de Investigaciones Marinas (CSIC), Vigo (Spain). ORCID ID: https://orcid.org/0000-0001-8922-6775

${ }^{4}$ Department of Food Science and Technology, Instituto de Investigaciones Marinas (CSIC), Vigo (Spain). ORCID ID: https://orcid.org/0000-0002-3136-8137

* Corresponding Author: saubourg@iim.csic.es, +34986292762 (fax number)

\section{ACKNOWLEDGEMENTS}

Thanks to Department of Biology, Institute of Exact Sciences and Natural and Life Sciences, University Centre Ahmed Zabana of Relizane (Algeria) for the financial support of the internship of Mrs. Hanane Oucif. The authors thank Mr. Marcos Trigo and Mrs. Susana Calvo for their excellent technical assistance. This work was supported by the Consejo Superior de Investigaciones Científicas (CSIC, Spain; project PIE 201370E001).

Keywords: West Algerian seaweeds; proximate composition; lipids and minerals; nutrition support; human diet 


\title{
Chemical composition and nutritional value of different seaweeds from the west Algerian coast
}

\begin{abstract}
Analysis of proximate composition, lipid fraction (fatty acids, lipid classes), macroelements and trace elements was carried out on brown (Cystoseira stricta; Cystoseira compressa), red (Corallina elongata) and green (Enteromorpha compressa; Ulva lactuca) seaweeds collected from the west Algerian coast, to assess their nutritional value. Protein, lipid, carbohydrate and ash content $\left(\mathrm{g} \mathrm{kg}^{-1}\right.$ dry alga) was in the ranges $58.5-141.4,6.4-27.1,134.0-461.1$ and $246.1-764.2$, respectively. The lowest caloric value was obtained for C. elongata (827.6 kcal kg-1 dry alga), the remaining values being in the range $2,106-2,479 \mathrm{kcal} \mathrm{kg}^{-1}$ dry alga. $C$. elongata and $C$. stricta provided the highest PUFA content, while a valuable $n-6 / n-3$ ratio of between 0.95 and 4.20 was obtained for all species. $\alpha$-Tocopherol was present in all seaweeds, the highest level being obtained in U. lactuca. Macroelements $\mathrm{K}$ and $\mathrm{Na}$ were predominant in C. compressa and C. stricta, $\mathrm{Mg}$ and $\mathrm{Ca}$ being most abundant in $E$. compressa and $C$. elongata, respectively. In all cases, a healthy $\mathrm{Na} / \mathrm{K}$ value $<0.7$ was observed, while a profitable ion quotient ratio was observed in all cases, except for $C$. elongata. Estimated daily intake of most minerals from the algae studied is lower than the corresponding recommended daily intake.
\end{abstract}

Keywords: West Algerian seaweeds; proximate composition; lipids and minerals; nutrition support; human diet

Running head: Nutritional value of west Algerian seaweeds. 
Seaweeds, the popular term for marine macroalgae, are classified based on anatomy, pigmentation, morphology, chemical composition and other characteristics as green (chlorophyte), brown (phaeophyte) and red (rhodophyte) algae (Dawczynski et al., 2007). In general, marine algae can produce a great variety of secondary metabolites with biological activity, being rich in vitamins such as $\mathrm{A}, \mathrm{B}_{1}, \mathrm{~B}_{12}, \mathrm{C}, \mathrm{D}$ and $\mathrm{E}$ and in minerals such as $\mathrm{Ca}, \mathrm{P}$ and $\mathrm{K}$ (Gupta and Abu-Ghannam, 2011). Most seaweeds contain a high ash (84-436 $\mathrm{g} \mathrm{kg}^{-1}$ dry alga) and fibre (53-523 $\mathrm{g} \mathrm{kg}^{-1}$ dry alga) content, low protein levels (49-378 $\mathrm{g} \mathrm{kg}^{-1}$ dry alga) and small amounts of fat $\left(9.2-52 \mathrm{~g} \mathrm{~kg}^{-1}\right.$ dry alga) (Hamid et al., 2015). Furthermore, red and green species have been shown to be rich in carbohydrates, whereas iodine and soluble fibre are reported to be abundant in brown algae. Interestingly, different authors have shown that the chemical composition of seaweeds can vary with species, maturity, habitat and environmental conditions (Burtin, 2003; Ortiz et al., 2006).

As a result of this high nutritional value, seaweeds have been harvested for a variety of uses and exploitation such as phycocolloid and iodine extraction, biofuel and fertiliser production, aquaculture feed and human consumption (Fleurence, 1999). Macroalgae are known to be a good source of healthy constituents that can inhibit the oxidation of low-density lipoproteins and play an important role in the arachidonic acid chain by inhibiting the formation of prostaglandins and thromboxane (Vazhiyil, 2008). The lipid composition of marine algae has also raised considerable interest due to the high content of polyunsaturated fatty acids (PUFA), especially C18:3n-3, C18:4n-3, C20:4n-6, C20:5n-3 and C22:6n-3 acids. These fatty acids have been shown to play an important role in the prevention of cardiovascular diseases, osteoarthritis and diabetes, and have been reported to possess antimicrobial, antiviral, anti-inflammatory and 
antitumoural properties (Dawczynski et al., 2007). Interestingly, great variability in lipid class content and fatty acid profiles has been observed according to species, geographical location, season, temperature, salinity, light intensity, nutrient availability and physiological stage (Yaich et al., 2011). Furthermore, the majority of the macroelements and trace elements needed for human nutrition and development can be found in macroalgae (El-Said and El-Sikaily, 2013; Bonanno and Orlando-Bonaca, 2018); such elements are considered essential for biological processes, including growth, reproduction, hormone metabolism and antioxidant defence.

Previous studies related to seaweeds from the Algerian coast can be considered scarce. Chemical and biological evaluation of the nutritive value of Ulva lactuca has been done (Zitouni et al., 2014), while the antioxidant properties of Asparagopsis taxiformis (Mellouk et al., 2017) and the antimicrobial behaviour of a combined ethanol-aqueous extract of Cystoseira compressa have been demonstrated (Oucif et al., 2018). Knowledge of the chemical composition and nutritional value is necessary so that utilisation of algae from such a North African coast can be increased and they can be widely exploited commercially.

Consequently, the present study explored the proximate composition (moisture, ash, proteins, lipids and carbohydrates), lipid composition (fatty acid profile and content of phospholipids, sterols, free fatty acids and tocopherol compounds) and mineral composition (macroelements and trace elements, essential and toxic) of five abundant seaweed species from the west Algerian coast (Cystoseira stricta, Cystoseira compressa, Corallina elongata, Enteromorpha compressa and Ulva lactuca). The primary objective of the current research was to provide information about their possible nutritional benefits for the human diet. 


\section{Sampling and processing}

78

79

80

Fresh C. stricta, C. compressa, C. elongata, E. compressa and U. lactuca were collected in May 2016 on the Oran coast, Western Algeria $\left(35^{\circ} 44^{\prime} 29.72^{\prime \prime} \mathrm{N}\right.$ and $\left.0^{\circ} 50^{\prime} 14.21^{\prime \prime} \mathrm{W}\right)$. A total weight of $1 \mathrm{~kg}$ was taken for each alga that was split into three independent groups that were analysed separately $(n=3)$. Species identification was made in the Laboratory of Aquaculture and Bioremediation by employing the Algabase site (www.algabase.com). Upon arrival to the laboratory, alga samples were washed thoroughly with running water to remove salts, sand and epiphytes. Biomass was then washed with distilled water and dried at room temperature $\left(23 \pm 2{ }^{\circ} \mathrm{C}\right)$ for $72 \mathrm{~h}$ in the dark. Then, the dried material was milled, powdered and stored at $-20{ }^{\circ} \mathrm{C}$ until further analysis.

\section{Proximate analysis}

Moisture was determined in fresh algae by drying to constant weight at $105 \pm 2{ }^{\circ} \mathrm{C}$ for $4 \mathrm{~h}$, according to official method 950.46B (AOAC, 1990); results were calculated as $\mathrm{g} \mathrm{kg}^{-1}$ wet weight.

Protein content $(N \times 6.25)$ was determined by the Kjeldahl method, in agreement with procedure 928.08 (alternative II; AOAC, 1990). The lipid fraction was extracted and quantified gravimetrically according to the method of Sánchez-Machado et al. (2002). Ash was determined at $550{ }^{\circ} \mathrm{C}$ by official method 920.153 (AOAC, 1990). Carbohydrates were estimated by difference. The content of proteins, lipids, carbohydrates and ash was calculated as $\mathrm{g} \mathrm{kg}^{-1}$ dry alga.

The caloric value $\left(\mathrm{kcal} \mathrm{kg}^{-1}\right.$ dry alga) was calculated by multiplying protein, carbohydrate and lipid values by a factor of 4, 4 and 9, respectively (FAO, 2003). 


\section{Lipid class analysis}

103

104

105

The phospholipid (PL) content in the lipid extract was measured according to the method of Raheja et al. (1973), which is based on formation of a complex with ammonium molybdate. Results were calculated as $\mathrm{g} \mathrm{PL} \mathrm{kg}^{-1}$ lipids.

The sterol (ST) content in the lipid extract was assessed by the method of Huang et al. (1961), based on the Liebermann-Buchardt reaction. Results were calculated as g ST kg-1 lipids.

The free fatty acid (FFA) content in the lipid extract was determined following the method of Lowry and Tinsley (1976), which is based on the formation of a complex with cupric acetate-pyridine. Results were calculated as $\mathrm{g} \mathrm{FFA} \mathrm{kg}{ }^{-1}$ lipids.

The profile of tocopherol compounds was analysed according to the method of Cabrini et al. (1992). For this, dry algae were extracted with hexane which was eliminated under nitrogen flux. The resulting alga extracts were then dissolved in isopropanol and injected into an HPLC system (ODS column, $15 \mathrm{~cm} \times 0.46 \mathrm{~cm}$ i.d.); detection was achieved at $280 \mathrm{~nm}$. The presence of different tocopherol compounds $(\alpha$, $\beta, \gamma$ and $\delta$ ) was checked, their content being calculated with calibration curves prepared from the corresponding commercial tocopherols. For each tocopherol compound, results were expressed as $\mathrm{mg} \mathrm{kg}^{-1}$ dry alga.

\section{Analysis of the fatty acid profile}

Lipid extracts were converted into fatty acid methyl esters (FAME) by using acetyl chloride, being then analysed by gas-liquid chromatography (Perkin Elmer 8700 chromatograph, Madrid, Spain) (Álvarez et al., 2009). Peaks corresponding to FAME were identified by comparison of their retention times with those of standard mixtures 
126 (Qualmix Fish, Larodan, Malmo, Sweden; FAME Mix, Supelco, Inc.). Peak areas were 127 automatically integrated; C19:0 fatty acid was used as an internal standard for 128 quantitative purposes. The content of each fatty acid (FA) was expressed as $\mathrm{g} 100 \mathrm{~g}^{-1}$ of total FA.

Results concerning FA groups (saturated, SFA; monounsaturated, MUFA; PUFA; $n$-3 PUFA; $n-6$ PUFA) and $n-6 / n-3$ ratio were also calculated.

\section{Mineral analysis}

The content of 22 minerals was analysed according to the following procedure based on EPA 3050B (US-EPA, 1996). About $1 \mathrm{~g}$ of ground sample was put into a digestion flask with $9 \mathrm{~mL}$ of hyperpure $69 \%$ nitric acid (TMA), $3 \mathrm{~mL}$ of $\mathrm{H}_{2} \mathrm{O}_{2}$ (for ultratrace analysis) and $3 \mathrm{~mL}$ of Milli-Q water. The sample was then digested in a microwave oven (MarsXpress CEM Corp., Matthews, NC, USA). After digestion treatment, samples were analysed for $\mathrm{Hg}$ using a flow injection mercury system (FIMS; 400 Perkin Elmer; emission lamp: $253.7 \mathrm{~nm}$ ) and for the other elements using inductively coupled plasma optical emission spectrometry (ICP-OES; Perkin Elmer Optima 4300 DV) for which the following working conditions were employed: $1,300 \mathrm{~W}$ (power), $15 \mathrm{~L} \mathrm{~min}^{-1}$ (plasma gas flow rate), $0.2 \mathrm{~L} \mathrm{~min}^{-1}$ (auxiliary gas flow rate) and $0.6 \mathrm{~L} \mathrm{~min}^{-1}$ (carrier gas flow rate). Accuracy of the analytical procedures was ensured using certified reference material (duck weed aquatic plant; BCR-670) prepared by the Institute for Reference Materials and Measurements (Table 1). Results obtained were calculated as $\mathrm{g} \mathrm{kg}^{-1}$ dry alga for macroelements and as $\mathrm{mg} \mathrm{kg}^{-1}$ dry alga for trace elements. 
150 Data $(n=3)$ obtained from the different chemical analyses were subjected to one-way ANOVA $(p<0.05)$ to investigate differences among the five different alga species (Statistica version 6.0, 2001; Statsoft Inc.). Comparison of means was performed using a least-squares difference (LSD) method.

\section{RESULTS AND DISCUSSION}

156

157

158

\section{Proximate composition}

Analysis of moisture content revealed great differences among the different algae under study (Table 2); values ( $\mathrm{g} \mathrm{kg}^{-1}$ fresh alga) varied between 840.0 for C. compressa and 470.5 for $C$. elongata, so that the following increasing sequence was obtained for alga groups: red $<$ green $<$ brown. The present results are in agreement with previous data on related species such as the brown alga Cystoseira abies-marina ( $838.0 \mathrm{~g} \mathrm{~kg}^{-1}$ fresh alga) (Patarra et al., 2011) and red alga Jania rubens (445.5 $\mathrm{g} \mathrm{kg}^{-1}$ fresh alga) (Polat and Özogul, 2009).

Regarding protein content, the red seaweed Corallina elongata showed the lowest $(p<0.05)$ level (Table 2 ), thus providing similar values to the red alga $C$. officinalis (59.1 $\mathrm{g} \mathrm{kg}^{-1}$ dry alga) (Ismail, 2017). Meanwhile, the highest average protein values were found in C. stricta, followed by E. compressa and U. lactuca. Opposite results have been obtained previously for protein content when comparing brown, red and green seaweeds. Fleurence (1999) reported that brown seaweeds contained lower levels of protein $\left(30-150 \mathrm{~g} \mathrm{~kg}^{-1}\right.$ dry alga) than green seaweeds $\left(90-260 \mathrm{~g} \mathrm{~kg}^{-1}\right.$ dry alga), while Anitha et al. (2008) reported that phaeophytes generally have higher protein content than other kinds of seaweed. Interestingly, lower protein levels $\left(28.9 \mathrm{~g} \mathrm{~kg}^{-1}\right.$ dry alga) than in the current study were obtained by Ozgun and Turan (2015) for $C$. 
compressa collected from the north-eastern Mediterranean coast of Turkey, and for $U$.

175 lactuca obtained in the north-east of Hong Kong (70.6 $\mathrm{g} \mathrm{kg}^{-1}$ dry alga; Wong and

176 Cheung, 2000) and from the Tunisian coast (84.6 $\mathrm{g} \mathrm{kg}^{-1}$ dry alga; Yaich et al., 2011).

177 Meanwhile, a higher protein level than in the current study was determined in $E$.

178 compressa (266.2 $\mathrm{g} \mathrm{kg}^{-1}$ dry alga) collected from the Azorean coast by Patarra et al. 179 (2011).

Seaweeds are known to have a relatively low lipid content $\left(10-50 \mathrm{~g} \mathrm{~kg}^{-1}\right.$ dry alga), with strong differences among species (Burtin, 2003). In agreement with Gosch et al. (2012), the brown seaweeds investigated in the current study showed the highest lipid content $(p<0.05)$, followed by green and red seaweeds (Table 2$)$. Thus, the values obtained in the current study can be considered to be in the range reported by Dawczynski et al. (2007) for brown seaweeds (10-45 $\mathrm{g} \mathrm{kg}^{-1}$ dry alga). Furthermore, similar lipid contents to those obtained in the present study for $U$. lactuca and $E$. compressa were recorded by Zitouni et al. (2014) and Kasimala et al. (2017) when collected from the Algerian and Eritrean coasts, respectively. In agreement with the low content determined in the current study for $C$. elongata, previous research has also shown low fat levels for the Corallinaceae family (1-23 $\mathrm{g} \mathrm{kg}^{-1}$ dry alga) (WielgoszCollin et al., 2016).

Carbohydrates are an abundant biochemical constituent in algae and represent the main energy source for the development of the different metabolic routes. Except for C. elongata, this constituent was the most abundant after moisture (Table 2). Thus, the green algae E. compressa and $U$. lactuca showed the highest content $(p<0.05)$, followed by both brown algae studied; interestingly, C. elongata had a markedly lower value $(p<0.05)$. The results of the current study are in agreement with those of 
carbohydrate content in seaweed groups: green $>$ brown $>$ red. As an explanation, chlorophytes are reported to grow in very shallow waters, so that the resulting high exposure to sunlight makes them synthesise more carbohydrates by photosynthesis (Kasimala et al., 2017). In agreement with the present values, previous research on

203 chlorophyte species has reported a carbohydrate content in the 434-602 $\mathrm{g} \mathrm{kg}^{-1}$ dry alga range, while E. compressa collected from the Indian coast showed a value of $482 \mathrm{~g} \mathrm{~kg}^{-1}$ dry alga (Mamatha et al., 2007).

Ash was the most abundant $(p<0.05)$ constituent in $C$. elongata (Table 2); a high content has also been reported in other Corallinaceae algae such as C. officinalis (778 $\mathrm{g} \mathrm{kg}^{-1}$ dry alga) (Marsham et al., 2007) and J. rubens $\left(807.3 \mathrm{~g} \mathrm{~kg}^{-1}\right.$ dry alga) (Polat and Özogul, 2009). In the current study, ash values for brown and green seaweeds ranged from 246.1 to $320.4 \mathrm{~g} \mathrm{~kg}^{-1}$ dry alga, values similar to those found in previous research for E. flexuosa and U. fasciata collected in coastal areas of Hawaii (232 and $322 \mathrm{~g} \mathrm{~kg}^{-1}$ dry alga, respectively; McDermid et al., 2007) and for Cystoseira corniculata from north-eastern Mediterranean coasts $\left(290 \mathrm{~g} \mathrm{~kg}^{-1}\right.$ dry alga; Polat and Özogul, 2009).

The lowest caloric value was obtained for C. elongata ( $827.6 \mathrm{kcal} \mathrm{kg}^{-1}$ dry alga), while levels corresponding to green and brown seaweeds were in the range 2,106$2,479 \mathrm{kcal} \mathrm{kg}^{-1}$ dry alga (i.e., $8.81-10.37 \mathrm{~kJ} \mathrm{~g}^{-1}$ dry alga). The energy values obtained in the current study are in agreement with those obtained for the Hawaiian brown seaweeds Sargassum echinocarpum and Dictyota acutiloba $\left(8.85\right.$ and $10.14 \mathrm{~kJ} \mathrm{~g}^{-1}$ dry alga, respectively) and green seaweeds U. fasciata and E. flexuosa $(9.95$ and $11.07 \mathrm{~kJ}$ $\mathrm{g}^{-1}$ dry alga, respectively) (McDermid et al., 2007). 


\section{Lipid class analysis}

224 Assessment of PL showed great differences among the alga species under study

225 (Table 3). Values for the PL content ranged from 54.4 (U. lactuca) to $191.6 \mathrm{~g} \mathrm{~kg}^{-1}$ lipids

(C. stricta), so that the following increasing sequence for seaweeds groups was attained:

227 green $<$ red $<$ brown, in agreement with a previous comparative study on different kinds of algae (Kumari et al., 2013). In contrast, lower PL values have been pointed out for brown seaweeds in other previous reports. Le Tutour et al. (1998) recorded $47 \mathrm{~g} \mathrm{~kg}^{-1}$ lipids in Fucus vesiculosus and Ascophyllum nodosum, while $27 \mathrm{~g} \mathrm{~kg}^{-1}$ lipids was recorded for $F$. serratus. Meanwhile, an average value of $220 \mathrm{~g} \mathrm{~kg}^{-1}$ lipids was signalled for the red alga Grateloupia turuturu.

ST content ranged from 100.8 (U. lactuca) to $161.9 \mathrm{~g} \mathrm{~kg}^{-1}$ lipids (E. compressa) (Table 3). Comparison among the different seaweed groups did not lead to a definite trend. However, previous studies signalled that algae from the genus Cystoseira were very rich in bioactive terpenes and ST (Shalaby, 2011). Among macroalgae, cholesterol has been shown to be the most abundant ST in all rhodophyte species, fucosterol being the most abundant in phaeophytes, and isofucosterol among chlorophytes (Kendel et al., 2015). Interestingly, phytosterols have been reported to provide beneficial effects, including inhibition of cholesterol absorption, as well as anticancer, antioxidant, antidiabetic, anti-inflammatory, antibacterial, antifungal and antiulcerative actions (Balboa et al., 2013).

The highest FFA content $(p<0.05)$ was recorded in $C$. elongata (198.7 $\mathrm{g} \mathrm{kg}^{-1}$ lipids), while values obtained for green and brown algae were in the range 103.9-139.8 $\mathrm{g} \mathrm{kg}^{-1}$ lipids (Table 3). FFA are important intermediate compounds during metabolism changes in living bodies. To our knowledge, no previous description of the FFA content in alga species has been provided up to now. 
249 Qualitative analysis showed that $\beta$-tocopherol was not detected in any of the algae under study. Furthermore, C. compressa and U. lactuca contained $\alpha$-, $\gamma$-, and $\delta$-tocopherol compounds, while E. compressa showed the presence of $\alpha$ - and $\delta$-tocopherol, and $C$. stricta and C. elongata contained only $\alpha$-tocopherol. Higher levels of vitamin E (i.e., $\alpha$ tocopherol) have previously been reported in brown seaweeds, especially for the genera Fucus and Ascophyllum (Burtin, 2003). In the current study, the highest amount of $\alpha$ tocopherol was found in E. compressa, while $\delta$-tocopherol was found to be especially abundant in $U$. lactuca. Great interest has been focused on vitamin $\mathrm{E}$ content in food and food products in agreement with its preservative effect in the antioxidant defence system. The data from the current study indicate a very high amount of $\alpha$-tocopherol in all seaweeds when compared to those reported for $U$. lactuca collected from the northern coast of Chile $\left(9.3 \mathrm{mg} \mathrm{kg}^{-1}\right.$ dry alga; Ortiz et al., 2006) and for other seaweeds obtained from the Galician coast (north-western Spain) (Laminaria ochroleuca, $8.9 \mathrm{mg} \mathrm{kg}^{-1}$ dry alga; Himanthalia elongata, 12.0-33.3 $\mathrm{mg} \mathrm{kg}^{-1}$ dry alga) (SánchezMachado et al., 2002).

\section{Fatty acid analysis}

Concerning the FA composition, the major SFA in all kinds of algae was C16:0 (Table 4). Other SFA present in all samples were C14:0 and C18:0. Comparison among seaweeds showed that E. compressa had the highest C16:0 average level, but the lowest for C14:0 and C18:0. In contrast, C. stricta had the highest average values for C14:0 and $\mathrm{C} 18: 0$, but the lowest for C16:0. The presence and content of such a main FA are in agreement with the results obtained by Polat and Özogul (2009) for brown (Cystoseira corniculata and Padina pavonica) and red (Laurencia papillosa and Jania rubens) 
seaweeds collected from the north-eastern Mediterranean coast and with those focused on algae of the genus Cystoseira (C. compressa, C. humilis, $C$. tamariscifolia, $C$. nodicaulis and C. baccata) obtained from the Algarve coast (Portugal) (Vicetto-Duarte et al., 2015).

In the seaweeds in the current study, the most abundant MUFA were C16:1n-9, C18:1n-9 and C18:1n-7 (Table 4). As for SFA, the content of individual MUFA varied among the alga species under study. Thus, C18:1n-7 was the most abundant in green seaweeds, whereas in brown and red seaweeds C18:1n-9 was most abundant. VizettoDuarte et al. (2015) also reported C18:1n-9 acid as the main MUFA in brown seaweeds, accounting for $9 \%$ and $17 \%$ in C. tamariscifolia and C. compressa collected from the south Portuguese coast, respectively.

There were remarkable differences in PUFA composition among the algae in the current study (Table 4). In agreement with previous studies on different kinds of marine algae from the Pacific coast of North California (Khotimchenko et al., 2002), the major PUFA in brown algae was C20:4n-6. For the green alga E. compressa, C18:2n-6 was the most abundant. It is interesting that a relatively high $\mathrm{C} 22: 5 n-3$ content $(5.39 \%)$ was detected in $U$. lactuca since this FA has often been described as being present at trace levels $(<1 \%)$ in most algae species (Tabarsa et al., 2012). Beneficial effects such as inhibition of platelet aggregation and strong endothelial cell migration ability have been described by Kaur et al. (2011) for this acid. On the other hand, the present data show that the red seaweed $C$. elongata could be an interesting source of C20:5n-3 (15.82\%). Gosch et al. (2012) also reported that C20:5n-3 was the most abundant essential PUFA in red seaweeds, especially in Champia parvula. Interestingly, $n-3$ PUFA have been shown to compete with the conversion of linoleic acid to arachidonic acid, thus regulating the relative amounts of $n-3$ and $n-6$ PUFA (Calder, 2012); among $n$-3 PUFA, 
C20:5n-3 has proven potential beneficial application for different kinds of illnesses. A

299

300

301

302

303

304

305

306

307

308

309

310

311

312

313

314

315

316

317

318

319

320

321

322

low presence of the essential $\mathrm{C} 22: 6 n-3$ was found in the current study for all alga species, the highest content being found in brown seaweeds. This acid is generally absent or has been reported to be present at low levels in different phaeophytes, according to previous research on Cystoseira nodicaulis, C. tamariscifolia and $C$. usneoides (Silva et al., 2013).

Concerning the analysis of FA groups (Fig. 1), the SFA group was the most abundant in all seaweeds, with values from $44.64 \%$ in $C$. stricta to $59.40 \%$ in $C$. compressa. Meanwhile, the MUFA content ranged from $18.03 \%$ in C. elongata to $37.49 \%$ in $U$. lactuca. However, comparison among the alga groups currently under study did not lead to a general distribution trend for both FA groups. Concerning PUFA, their content varied between $14.02 \%$ in $U$. lactuca and $32.34 \%$ in C. elongata. Interestingly, the following decreasing sequence for PUFA average content was implied for the seaweed groups under study: red $>$ brown $>$ green. Differences in FA group distribution led to great differences in the PUFA/SFA ratio, so that a value of 0.28 was obtained for U. lactuca, while C. elongata reached a markedly higher score (0.65).

Distribution of PUFA between $n-6$ and $n-3$ series is depicted in Fig. 2. Thus, the highest proportion of $n$-3 PUFA was found in C. elongata (16.62\%) and the lowest in $E$. compressa $(3.37 \%)$. On the other side, the highest $n$-6 PUFA values were obtained for C. stricta (17.72\%), while the lowest scores were found for U. lactuca $(6.89 \%)$. Concerning both PUFA series (i.e., $n-3$ and $n-6$ ), great attention has recently been accorded to the $n-6 / n-3$ ratio. In order to prevent inflammatory, cardiovascular and neurological disorders, the World Health Organization (WHO) currently recommends that this ratio should not exceed 10 in the human diet (Kumari et al., 2013); additionally, the European Nutritional Society reported that a human diet with an 
$n-6 / n-3$ ratio of $5: 1$ or lower would have health benefits (Simopoulos, 2002). In the current study, the $n-6 / n-3$ ratio ranged from 0.95 (C. elongata) to 4.20 (E. compressa) (Fig. 2). Consequently, and in agreement with recommended values, the lipid composition of all alga species under study can be considered as profitable and highly valuable from a health point of view.

\section{Mineral content}

Macroelement results (Table 5) indicate that brown seaweeds have a higher $(p<0.05) \mathrm{K}$ and $\mathrm{Na}$ content than the green and red algae of the present study. Similarly, El-Said and El-Sikaily (2013) observed that green seaweeds showed smaller average $\mathrm{Na}$ and $\mathrm{K}$ values than brown seaweeds from the Egyptian Mediterranean Sea coast. Furthermore, in a comparative study of seaweeds from the Persian Gulf, Rohani-Ghadikolaei et al. (2012) also found higher $\mathrm{K}$ contents in brown seaweeds. Concerning $\mathrm{Mg}$, the current study showed that this element was the most abundant $(p<0.05)$ in the green and red algae tested. High values (38.9 $\mathrm{g} \mathrm{kg}^{-1}$ dry alga) were also obtained by Yaich et al. (2011) when analysing U. lactuca collected from the Tunisian coast. In this study, Ca was the most abundant element in the red seaweed $C$. elongata; a similar result was reported by Polat and Özogul (2009) in other red algae such as L. papillosa and J. rubens when compared to brown algae (Cystoseira corniculata and P. pavonica). Such a high $\mathrm{Ca}$ amount in the current research can be explained on the basis that C. elongata is a calcareous alga, this implying a marked Ca presence.

Great attention is being accorded nowadays to the $\mathrm{Na} / \mathrm{K}$ ratio in the human diet. Yang et al. (2011) found a reduced risk of cardiovascular diseases if a $\mathrm{Na} / \mathrm{K}$ ratio $<1.0$ is present. Interestingly, a $\mathrm{Na} / \mathrm{K}$ ratio below 0.7 was found in all the seaweeds in the current study (Table 5). 

ratio. This value can be calculated in agreement with the following formula, concentrations being given in moles (Kiss et al., 2004):

$$
\text { Ion quotient }=\left(\left[\mathrm{Ca}^{+2}\right]+\left[\mathrm{Na}^{+}\right]\right) /\left(\left[\mathrm{Mg}^{+2}\right]+\left[\mathrm{K}^{+}\right]\right)
$$

Low molar ratios $(0.41,0.43,0.55$ and 0.77$)$ were determined for $C$. compressa,

of such seaweed species in foods could lead to a decrease of the ion quotient range in the human body (2.5-4.0) and reduce the development of related diseases such as hypertension, preeclampsia and heart disease (El-Said and El-Sikaily, 2013; Ismail et al., 2017). However, C. elongata showed a markedly higher value (4.54), so this alga would not be recommended for use in food (Table 5).

Marked differences in trace element content were found among the five alga species, although Sr, Fe and B were in general the most abundant (Table 5). The highest presence of $\mathrm{Sr}$ was observed in C. elongata. Furthermore, a definite trend among alga groups was observed for Sr content according to the following increasing sequence: red $<$ brown $<$ green. Interestingly, $\mathrm{Sr}$ is known to be necessary to stimulate the growth of coral, being fixed in its skeleton at the same time as Ca. Concerning Fe and B content, the highest average values were found in E. compressa and C. compressa, respectively. The highest $(p<0.05)$ concentrations of $\mathrm{As}, \mathrm{Ba}, \mathrm{Cd}$ and $\mathrm{Rb}$ were recorded in brown seaweeds (Table 5). The predominant trace elements in green seaweeds were $\mathrm{Cr}$, $\mathrm{Cu}$ and $\mathrm{V}$, while $C$. elongata showed the highest average levels for $\mathrm{Li}, \mathrm{Mn}, \mathrm{Zn}, \mathrm{Pb}$ and Sr. Co was found in low concentrations in all algae in the current study, in accordance with the results of Krishnaiah et al. (2008). Polat and Özogul (2009) also found that the 
373 Mn and Zn content was higher in red (L. papillosa and J. rubens) algae than in brown

374 (C. corniculata and P. pavonica) ones when comparing algae from the north-eastern

375 Mediterranean coast. Furthermore, similar levels of $\mathrm{As}, \mathrm{Cd}, \mathrm{Cr}, \mathrm{Cu}, \mathrm{Hg}, \mathrm{Mn}, \mathrm{Ni}, \mathrm{Pb}$ and

376 Zn were recorded by Bonanno and Orlando-Bonaca (2018) in different kinds of brown,

377 red and green seaweeds collected from the Mediterranean coasts when compared to

378 those obtained in the current study. Meanwhile, all seaweeds under study showed the

379 presence of Se; this element has recently been reported to be a health-promoting

380 ingredient in foods as it is related to an endogenous antioxidant system (Fairweather-

381 Tait et al., 2011).

The levels of total As varied over a wide range (4.4-141.0 $\mathrm{mg} \mathrm{kg}^{-1}$ dry alga) in the algae in the current study, in agreement with the data provided by Almela et al. (2002) for 18 alga-derived commercial products related to brown, red and green seaweeds $\left(2.0-172 \mathrm{mg} \mathrm{kg}^{-1}\right.$ dry alga range). Remarkably, brown algae provided the highest $(p<0.05)$ levels of the element in the current study, thus showing a greater capacity for its accumulation. It is worth pointing out that As has been reported to exist both in inorganic (toxic) and organic (non-toxic) forms, the less toxic form being more abundant as is the case for arsenic-sugar compounds. It is important to point out that the brown alga Hizikia fusiforme provides a high inorganic As content (60-72\% of the total As) (Almela et al., 2002). In the present research, both forms of As have been measured altogether, so that differentiation between toxic and non-toxic As cannot be carried out. The estimated daily intake in adults for trace elements related to non-cancerous health content was calculated using the following equation (Herbicide Risk Assessment for the Aquatic Plant Management Final Supplemental Environmental Impact Statement, 2001; Health Consultation, Land Crab Evaluation, National Oceanographic 
400

401

402

403

404

405

406

407

408

409

410

411

412

where $\mathrm{C}$ is the average concentration $\left(\mathrm{mg} \mathrm{kg}^{-1}\right)$ of the contaminant element, IR is ingestion rate $\left(0.227 \mathrm{~kg} \mathrm{day}^{-1}, 8 \mathrm{oz}\right.$ meal, for adults), $\mathrm{EF}$ is exposure frequency or number of exposure events per year of exposure ( 365 days year $\left.^{-1}\right)$, ED is exposure time (70 years), BW is body weight $(70 \mathrm{~kg})$ and $\mathrm{AT}$ is average time (non-cancer/lifetime $=$

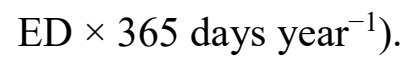

Among all the seaweeds in the current study, the brown species C. compressa and C. stricta showed the highest estimated daily intake values for Cd (1.32E-02 and 9.72E-03 mg kg ${ }^{-1}$ day $^{-1}$, respectively). Taking into account the maximum $\mathrm{Cd}$ level of $4.1 \mathrm{mg} \mathrm{kg}^{-1}$ dry alga, consumption of less than $73 \mathrm{~g}$ of this alga per day would mean ingestion of a lower percentage of Cd than the one established by the WHO (2006) (0.001 mg of $\mathrm{Cd} \mathrm{day}^{-1}$ for a body weight of $70 \mathrm{~kg}$ ). Table 6 also shows that in all seaweeds tested, the daily intakes of $\mathrm{Ca}, \mathrm{Mg}, \mathrm{K}, \mathrm{Na}, \mathrm{Cr}, \mathrm{Fe}, \mathrm{B}, \mathrm{Mn}, \mathrm{V}, \mathrm{Hg}, \mathrm{Pb}, \mathrm{Zn}, \mathrm{Cu}$, $\mathrm{Se}, \mathrm{Ni}$ and $\mathrm{Li}$ were lower than the recommended daily intakes for such elements (WHO, 1993; Trumbo et al., 2001; Institute of Medicine, 2005; WHO, 2006, 2011). 15

Information about the chemical composition, caloric value, lipid fraction (FA and lipid classes), macroelements and trace elements shows that the seaweeds studied can be considered as promising candidates for nutritional support to the human diet. Thus, the presence of $\alpha$-tocopherol and healthy $n-6 / n-3$ and $\mathrm{Na} / \mathrm{K}$ ratios were observed in all seaweeds. A profitable ion quotient ratio was obtained for all seaweeds, except for $C$. elongata. Furthermore, estimated daily intakes of most macroelements and trace 
423 elements are lower than the corresponding recommended daily intake. Knowledge of 424 this chemical composition would be profitable for identifying strains suitable for 425 pharmaceutical, feed or fertiliser applications. Interestingly, the five macroalgae studied 426 could be an alternative source of antioxidants, healthy FA and essential minerals to 427 meet the recommended daily intake of vitamin E, $n-3$ FA and trace elements. However, 428 before being used as a food component, the current data show that attention must be 429 paid to their heavy metal content by monitoring their levels to ensure chemical safety. 430 
Almela, C., Algora, S., Benito, V., Clemente, M. J., Devesa, V., Suner, M., Velez, D., and Montoro, R. 2002. Heavy metal, total arsenic, and inorganic arsenic contents of algae food products. J. Agric. Food Chem. 50:918-923.

AOAC. 1990. Official Methods of Analysis of the Association of Analytical Chemistry.

Anitha, A., Balamurugan, R., Swarnakumar, N., Sivakumar, K., and Thangaradjou, T. 2008. Evaluation of seaweeds for biochemical composition and calorific content. Seaweed Res. Utiln. 30:197-202.

Álvarez, V., Medina, I., Prego, R., and Aubourg, S. P. 2009. Lipid and mineral distribution in different zones of farmed and wild blackspot sea bream (Pagellus bogaraveo). Eur. J. Lipid Sci. Technol. 111:957-966.

$15^{\text {th }}$ ed. Arlington, VA, USA: Association of Official Chemists'. Pp. 931-937.

Balboa, E. M., Conde, E., Moure, A., Falqué, E., and Domínguez, H. 2013. In vitro antioxidant properties of crude extracts and compounds from brown algae. Food Chem. 138:1764-1785.

Bonanno, G., and Orlando-Bonaca, M. 2018. Trace elements in Mediterranean seagrasses and macroalgae. A review. Sci. Total Environ. 618:1152-1159.

Burtin, P. 2003. Nutritional value of seaweeds. Elec. J. Envir. Agric. Food Chem. 2:498-503.

Cabrini, L., Landi, L., Stefanelli, C., Barzanti, V., and Sechi, A. 1992. Extraction of lipid and lipophilic antioxidants from fish tissues: A comparison among different methods. Comp. Biochem. Physiol. Part B Biochem. Mol. Biol. 101:383-386.

Calder, P. C. 2012. Mechanisms of action of (n-3) fatty acids. J. Nutrit. 142:592S-599S.

Dawczynski, C., Schubert, R., and Jahreis, G. 2007. Amino acids, fatty acids, a dietary fibre in edible seaweed products. Food Chem. 103:891-899. 
El-Said, G. F., and El-Sikaily, A. 2013. Chemical composition of some seaweed from Mediterranean Sea coast, Egypt. Environ. Monit. Assessm. 185:6089-6099.

Fairweather-Tait, S. J., Bao, Y. P., Broadley, M. R., Collings, R., Ford, D., Hesketh, J. E., and Hurst, R. 2011. Selenium in human health and disease. Antioxid. Redox Signal. 14:1337-1383.

FAO. 2003. Food energy - Methods of analysis and conversion factors. Report of technical workshop. FAO Food and Nutrition paper No. 77. Rome, Italy.

Fleurence, J. 1999. Seaweed proteins: biochemical, nutritional aspects and potential uses. Trends Food Sci. Technol. 10:25-28.

Gosch, B. J., Magnusson, M., Paul, N. A., and De Nys, R. 2012. Total lipid and fatty acid composition of seaweeds for the selection of species for oil-based biofuel and bioproducts. GCB Bioenergy 4:919-930.

Gupta, S., and Abu-Ghannam, N. 2011. Bioactive potential and possible health effects of edible brown seaweeds. Trends Food Sci. Technol. 22:315-326.

Hamid, N., Ma, Q., Boulom, S., Liu, T., Zheng, Z., Balbas, J., and Robertson, J. 2015. Seaweed minor constituents. In: Seaweed Sustainability, food and non-food applications. Chapter 8. Troy, D. J. (Ed.). San Diego, CA, USA: Academic Press. Pp. 193-242.

Health Consultation, Land Crab Evaluation, National Oceanographic Atmospheric Administration Data. 2006. Isla de Vieques Vieques (p. 26). Puerto Rico: Department of Health and Human Services Agency for Toxic Substances and Disease Registry Division of Health Assessment and Consultation.

Herbicide risk assessment for the aquatic plant management final supplemental environmental impact statement. 2001. Appendix C, Volume 3, 2, 4-D, February 
(p. 435). Publication Number 00-10-043, Prepared by: Compliance Services International 1112, Alexander Avenue, Tacoma, WA, USA 98421.

483

484

485

Huang, T., Chen, C., Wefler, V., and Raftery, A. 1961. A stable reagent for the Liebermann-Buchardt reaction. Anal. Chem. 33:1405-1407.

Institute of Medicine. 2005. Dietary Reference Intakes for Water, Potassium, Sodium, Chloride, and Sulfate; Food and Nutrition Board, National Academy of Sciences. Washington, DC, USA: The National Academy Press

Ismail, G. A. 2017. Biochemical composition of some Egyptian seaweeds with potent nutritive and antioxidant properties. Food Sci. Technol. Campinas 37:294-302.

Ismail, M. M., El Zokm, G. M., and El-Sayed, A. A. M. 2017. Variation in biochemical constituents and master elements in common seaweeds from Alexandria Coast, Egypt, with special reference to their antioxidant activity and potential food uses: prospective equations. Environ. Monit. Assess. 189:1-17.

Kasimala, M. B., Mebrahtu, L., Mehari, A., and Tsighe, N. K. 2017. Proximate composition of three abundant species of seaweeds from red sea coast in Massawa, Eritrea. J. Algal Biom. Utiliz. 8:44-49.

Kaur, G., Cameron-Smith, D., Garg, M., and Sinclair, A. J. 2011. Docosapentaenoic acid (22:5n-3): a review of its biological effects. Prog. Lipid Res. 50:28-34.

Kendel, M., Wielgosz-Collin, G., Bertrand, S., Roussakis, C., Bourgougnon, N., and Bedoux, G. 2015. Lipid Composition, Fatty Acids and Sterols in the Seaweeds Ulva armoricana, and Solieria chordalis from Brittany (France): An Analysis from Nutritional Chemotaxonomic, and Antiproliferative Activity Perspectives. Mar. Drugs 13:5606-5628.

Khotimchenko, S. V., Vaskovsky, V. E., and Titlyanova, T. V. 2002. Fatty acids of marine algae from the Pacific coast of North California. Bot. Mar. 45:17-22. 
Kiss, S. A., Forster, T., and Dongo, A. 2004. Absorption and effect of the magnesium content of a mineral water in the human body. J. Am. Coll. Nutr. 23:758S-762S.

Krishnaiah, D., Sarbatly, R., Prasad, D. M., and Bono, A. 2008. Mineral content of some seaweeds from Sabah’s South China Sea. Asian J. Sci. Res. 1:166-170.

Kumari, P., Kumar, M., Reddy, C. R., and Jha, B. 2013. Algal lipids, fatty acids and sterols. In: Functional Ingredients from Algae for Foods and Nutraceuticals. Domínguez, H. (Ed.). Cambridge, UK: Woodhead Publishing. Pp. 87-134.

Le Tutour, B., Bensliman, F., Gouleau, M. P., Gouygou, J. P., Saadan, B., and Quemeneur, F. 1998. Antioxidant and pro-oxidant activities of the brown algae, Laminaria digitata, Himanthalia elongata, Fucus vesiculosus, Fucus serratus and Ascophyllum nodosum. J. App. Phycol. 10:121-129.

Lowry, R., and Tinsley, I. 1976. Rapid colorimetric determination of free fatty acids. J. Am. Oil Chem. Soc. 53:470-472.

Mamatha, B. S., Namitha, K. K., Senthil, A., Smitha, J., and Ravishankar, G. A. 2007. Studies on use of Enteromorpha in snack food. Food Chem. 101:1707-1713.

Marsham, S., Scott, G. W., and Tobin, M. L. 2007. Comparison of nutritive chemistry of a range of temperate seaweeds. Food Chem. 100:1331-1336.

McDermid, K. J., Stuercke, B. and Balazs, G. H. 2007. Nutritional composition of marine plants in the diet of the green sea turtle Chelonia mydas in the Hawaiian Islands. Bull. Mar. Sci. 811:55-71.

Mellouk, Z., Benammar, I., Krouf, D., Goudjil, M., Okbi, M., and Malaisse, W. 2017. Antioxidant properties of the red alga Asparagopsis taxiformis collected on the North West Algerian coast. Exp. Therap. Med. 13:3281-3290.

Ortiz, J., Romero, N., Robert, P., Araya, J., Lopez-Hernández, J., Bozzo, C., and Ríos, A. 2006. Dietary fiber, amino acid, fatty acid and tocopherol contents of the 

104.

533

534

Oucif, H., Miranda, J. M., Ali Mehidi, S., Abi-Ayad, S.-M., Barros-Velázquez, J., and Aubourg, S. P. (2018). Effectiveness of a combined ethanol-aqueous extract of alga Cystoseira compressa for the quality enhancement of a chilled fatty fish species. Eur. Food Res. Technol. 244:291-299.

Ozgun, S., and Turan, F. 2015. Biochemical composition of some brown algae from Iskenderun Bay, the northeastern Mediterranean coast of Turkey. J. Black Sea/Mediterranean Environ. 21:125-134.

Patarra, R. F., Paiva, L., Neto, A. I., Lima, E., and Baptista, J. 2011. Nutritional value of selected macroalgae. J. App. Phycol. 23:205-208.

Polat, S., and Özogul, Y. 2009. Fatty acid, mineral and proximate composition of some seaweeds from the north eastern Mediterranean coast. Ital. J. Food Sci. 21:317324.

Raheja, R., Kaur, C., Singh, A. and Bhatia, A. 1973. New colorimetric method for the quantitative determination of phospholipids without acid digestion. J. Lipid Res. 14:695-697.

Rohani-Ghadikolaei, K., Abdulalian, E., and Ng, W. K. 2012. Evaluation of the proximate, fatty acid and mineral composition of representative green, brown and red seaweeds. J. Food Sci. Technol. 49:774-780.

Sánchez-Machado, D. I., López-Hernández, J., and Paseiro-Losada, P. 2002. Highperformance liquid chromatographic determination of $\alpha$-tocopherol in macroalgae. J. Chrom A 976:277-284.

Shalaby, E. 2011. Algae as promising organisms for environment and health. Plant Sign. Behav. 6:1338-1350. 
Silva, G., Pereira, R. B., Valentão, P., Andrade, P. B., and Sousa, C. 2013. Distinct fatty acid profile of ten brown macroalgae. Rev. Bras. Farmacog. 23:608-613.

Simopoulos, A. P. 2002. The importance of the ratio of omega-6/omega-3 essential fatty acids. Biomed. Pharmacother. 56:365-379.

Tabarsa, M., Rezaei, M., Ramezanpour, Z., Robert Waaland, J. R., and Rabiei, R. 2012. Fatty acids, amino acids, mineral contents, and proximate composition of some brown seaweeds. J. Phycol. 48:285-292.

Trumbo, P., Yates, A. A., Schlicker, S., and Poos, M. 2001. Dietary Reference Intake: Vitamin A, vitamin K, arsenic, boron, chromium, copper, iodine, iron, manganese, molybdenum, nickel, silicon, vanadium, and zinc. J. Am. Diet. Assoc. 101:294-301.

US-EPA. 1996. United States Environmental Protection Agency. SW-846 Test Method 3050B: Acid Digestion of Sediments, Sludges, and Soils, Revision 2 (12 pages). Washington, $\quad$ DC; USA. Available: http://www.epa.gov/opptsfrs/publications/OPPTS_Harmonized/870_Health_Eff ects Test Guidelines/

Vazhiyil, V. 2008. Marine sources of vitamins and minerals. In: Marine Products for Healthcare: Functional and Bioactive Nutraceutical Compounds from the Ocean. Functional Foods and Nutraceuticals Series. Vazhiyil, V. (Ed.). Boca Raton, FL, USA: CRC Press Taylor and Francis Group. Pp. 239-259.

Vizetto-Duarte, C., Pereira, H., Bruno de Sousa, C., Rauter, A. P., Albericio, F., Custódio, L., Barreira L., and Varela, J. 2015. Fatty acid profile of different species of algae of the Cystoseira genus: a nutraceutical perspective. Nat. Prod. Res. 29:1264-1270. 
580

581

582

583

584

585

586

587

588

589

590

591

592

593

594

595

596

597

598

599

600

601

602

603

604

WHO. 1993. Evaluation of certain food additives and contaminants. Forty-First Report of the Joint FAO/WHO Expert Committee on Food Additives, WHO Technical Report Series No. 837. Geneva, Switzerland: WHO Press.

WHO. 2006. Evaluation of Certain Food Contaminants: Sixty-Fourth Report of the Joint FAO/WHO Expert Committee on Food Additives, WHO Technical Report Series No. 930. Geneva, Switzerland: WHO Press.

WHO. 2011. Evaluation of Certain Contaminants in Food: Seventy-Second Report of the Joint FAO/WHO Expert Committee on Food Additives; WHO Technical Report Series No. 959. Geneva, Switzerland: WHO Press.

Wielgosz-Collin, G., Kendel, M., and Couzinet-Mossion, A. 2016. Lipids, Fatty Acids, Glycolipids, and Phospholipids. In: Seaweed in Health and Disease Prevention. Chapter 7. Fleurence, J., and Levine, I. (Eds.). San Diego, CA, USA: Academic Press. Pp. 185-221.

Wong, K. H., and Cheung, P. C. 2000. Nutritional evaluation of some subtropical red and green seaweeds: Part I-proximate composition, amino acid profiles and some physico-chemical properties. Food Chem. 71:475-482.

Yaich, H., Garna, H., Besbes, S., Paquot, M., Blecker, C., and Attia, H. 2011. Chemical composition and functional properties of Ulva lactuca seaweed collected in Tunisia. Food Chem. 128:895-901.

Yang, Q., Liu, T., Kuklina, E. V., Flanders, W. D., Hong, Y., Gillespie, C., Chang, M., Gwinn, M., Dowling, N., Khoury, M., and Hu, F. 2011. Sodium and potassium intake and mortality among US adults: prospective data from the Third National Health and Nutrition Examination Survey. Arch. Int. Med. 171:1183-1191.

Zitouni, H., Arhab, R., Boudry, C., Bousseboua, H., and Beckers, Y. 2014. Chemical and biological evaluation of the nutritive value of Algerian green seaweed Ulva 

Res. 2:916-925.

607

608 


\section{$610 \quad$ Figure 1}

611 Fatty acid (FA) group (saturated, SFA; monounsaturated, MUFA; polyunsaturated,

612 PUFA) content* in different seaweeds from the west Algerian coast.

$613 *$ Data expressed as average values of three replicates $(n=3)$; standard deviations are 614 indicated by bars. For each FA group, average values accompanied by different $615 \quad$ letters $(\mathrm{a}-\mathrm{d})$ indicate significant differences $(p<0.05)$.

616

\section{Figure 2}

618 Content* of $n-3$ and $n-6$ polyunsaturated fatty acids (PUFA) in total fatty acids (TFA) 619 and $n-6 / n-3$ ratio in different seaweeds from the west Algerian coast.

* Data expressed as average values of three replicates $(n=3)$; standard deviations are indicated by bars. For each parameter, average values accompanied by different letters $(\mathrm{a}-\mathrm{e})$ indicate significant differences $(p<0.05)$. 


\section{TABLE 1}

Accuracy control of the analytical procedures for the determination* of macroelements and trace elements (average \pm SD)**

\begin{tabular}{lccc}
\hline \multicolumn{1}{c}{ Element } & Certified & Measured & Unit \\
\hline MACROELEMENTS & & & \\
\hline $\mathrm{Ca}$ & $\mathrm{nd}$ & & \\
$\mathrm{Mg}$ & $\mathrm{nd}$ & $4.91 \pm 0.19$ & $\mathrm{mg} \mathrm{kg}^{-1}$ \\
$\mathrm{~K}$ & $\mathrm{nd}$ & $24.44 \pm 0.93$ & $\mathrm{~g} \mathrm{~kg}^{-1}$ \\
$\mathrm{Na}$ & $\mathrm{nd}$ & $7.80 \pm 0.29$ & $\mathrm{~g} \mathrm{~kg}^{-1}$ \\
\hline $\mathrm{TRACE} \mathrm{ELEMENTS}$ & & & \\
\hline $\mathrm{As}$ & $1.98 \pm 0.19$ & $2.01 \pm 0.01$ & $\mathrm{mg} \mathrm{kg}^{-1}$ \\
$\mathrm{~B}$ & $\mathrm{nd}$ & $1480 \pm 40$ & $\mathrm{mgkg}^{-1}$ \\
$\mathrm{Ba}$ & $56.5 \pm 0.3$ & $54.9 \pm 1.1$ & $\mathrm{mgkg}^{-1}$ \\
$\mathrm{Cd}$ & $0.0755 \pm$ & $0.0752 \pm$ & $\mathrm{mg} \mathrm{kg}^{-1}$ \\
$\mathrm{Co}$ & 0.0025 & 0.0004 & \\
$\mathrm{Cr}$ & $1.25 \pm 0.22$ & $1.25 \pm 0.01$ & $\mathrm{mg} \mathrm{kg}^{-1}$ \\
$\mathrm{Cu}$ & $2.05 \pm 0.10$ & $2.01 \pm 0.01$ & $\mathrm{mg} \mathrm{kg}^{-1}$ \\
$\mathrm{Fe}$ & $1.82 \pm 0.30$ & $1.75 \pm 0.02$ & $\mathrm{mg} \mathrm{kg}^{-1}$ \\
$\mathrm{~Pb}$ & $1.01 \pm 0.01$ & $0.98 \pm 0.03$ & $\mathrm{~g} \mathrm{~kg}^{-1}$ \\
$\mathrm{Li}$ & $2.06 \pm 0.12$ & $2.01 \pm 0.02$ & $\mathrm{mg} \mathrm{kg}^{-1}$ \\
$\mathrm{Mn}$ & $1.48 \pm 0.03$ & $1.37 \pm 0.08$ & $\mathrm{mg} \mathrm{kg}^{-1}$ \\
$\mathrm{Hg}$ & $1.53 \pm 0.02$ & $1.50 \pm 0.03$ & $\mathrm{~g} \mathrm{~kg}^{-1}$ \\
$\mathrm{Ni}$ & $\mathrm{nd}$ & $8.1 \pm 1.6$ & $\mu \mathrm{gkg}^{-1}$ \\
$\mathrm{Rb}$ & $2.45 \pm 0.27$ & $2.51 \pm 0.02$ & $\mathrm{mg} \mathrm{kg}^{-1}$ \\
$\mathrm{Se}$ & $7.96 \pm 0.09$ & $8.02 \pm 0.05$ & $\mathrm{mg} \mathrm{kg}^{-1}$ \\
$\mathrm{Sr}$ & $0.183 \pm 0.040$ & $0.175 \pm 0.040$ & $\mathrm{mg} \mathrm{kg}^{-1}$ \\
$\mathrm{~V}$ & $180 \pm 1$ & $182 \pm 4$ & $\mathrm{mg} \mathrm{kg}^{-1}$ \\
$\mathrm{Zn}$ & $3.48 \pm 0.18$ & $3.51 \pm 0.02$ & $\mathrm{mg} \mathrm{kg}^{-1}$ \\
\hline & $24.0 \pm 2.1$ & $22.7 \pm 0.5$ & $\mathrm{mg} \mathrm{kg}^{-1}$ \\
\hline
\end{tabular}

* Data expressed as average values \pm standard deviation $(n=3$; three replicates); nd: no data. ** Certified reference material was Aquatic Plant BCR-CRM670 (GeoReM). 


\section{TABLE 2}

Proximate composition and caloric value* of different brown, red and green seaweeds collected from the west Algerian coast**

\begin{tabular}{lccccc}
\hline $\begin{array}{c}\text { Composition and } \\
\text { caloric value }\end{array}$ & \multicolumn{3}{c}{ Brown seaweed } & Red seaweed & Green seaweed \\
\cline { 2 - 6 } & C. compressa & C. stricta & C. elongata & E. compressa & U. lactuca \\
\hline Moisture & $840.0 \pm 0.0 \mathrm{a}$ & $802.5 \pm 0.1 \mathrm{~b}$ & $470.5 \pm 0.2 \mathrm{e}$ & $719.1 \pm 1.5 \mathrm{~d}$ & $749.4 \pm 5.2 \mathrm{c}$ \\
Proteins & $89.1 \pm 8.4 \mathrm{~b}$ & $141.4 \pm 0.3 \mathrm{a}$ & $58.5 \pm 0.6 \mathrm{c}$ & $136.1 \pm 6.7 \mathrm{a}$ & $125.4 \pm 0.7 \mathrm{a}$ \\
Lipids & $18.3 \pm 1.8 \mathrm{~b}$ & $27.1 \pm 0.1 \mathrm{a}$ & $6.4 \pm 0.3 \mathrm{~d}$ & $10.0 \pm 0.2 \mathrm{c}$ & $9.8 \pm 0.1 \mathrm{c}$ \\
Carbohydrates & $396.2 \pm 0.7 \mathrm{c}$ & $354.5 \pm 0.4 \mathrm{~d}$ & $134.0 \pm 1.1 \mathrm{e}$ & $461.1 \pm 10.8 \mathrm{a}$ & $428.1 \pm 2.8 \mathrm{~b}$ \\
Ash & $320.4 \pm 4.2 \mathrm{~b}$ & $246.1 \pm 1.7 \mathrm{~d}$ & $764.2 \pm 2.2 \mathrm{a}$ & $263.6 \pm 2.8 \mathrm{c}$ & $271.3 \pm 3.5 \mathrm{c}$ \\
Caloric value & $2,106 \pm 1 \mathrm{~d}$ & $2,227 \pm 0 \mathrm{c}$ & $827.6 \pm 0.0 \mathrm{e}$ & $2,479 \pm 2 \mathrm{a}$ & $2,303 \pm 1 \mathrm{~b}$ \\
\hline
\end{tabular}

* Data are expressed as average values of three replicates $(n=3) \pm$ standard deviations. For each row, average values followed by different letters (a-e) indicate significant ( $p<$ $0.05)$ differences.

** Chemical data calculated as $\mathrm{g} \mathrm{kg}^{-1}$ dry alga, except for moisture $\left(\mathrm{g} \mathrm{kg}^{-1}\right.$ fresh alga). Caloric value is expressed as kcal kg-1 dry alga. 


\section{TABLE 3}

Content* on phospholipids, sterols, free fatty acids and tocopherols of different brown, red and green seaweeds collected from the west Algerian coast

\begin{tabular}{lccccc}
\hline & \multicolumn{2}{c}{ Brown seaweed } & Red seaweed & \multicolumn{2}{c}{ Green seaweed } \\
\cline { 2 - 6 } & C. compressa & C. stricta & C. elongata & E. compressa & U. lactuca \\
\hline Phospholipids & $140.7 \pm 1.0 \mathrm{~b}$ & $191.6 \pm 5.5 \mathrm{a}$ & $83.7 \pm 3.9 \mathrm{c}$ & $82.9 \pm 12.0 \mathrm{c}$ & $54.4 \pm 0.5 \mathrm{~d}$ \\
Sterols & $135.9 \pm 7.2 \mathrm{~b}$ & $136.2 \pm 0.4 \mathrm{~b}$ & $104.3 \pm 5.5 \mathrm{c}$ & $161.9 \pm 4.3 \mathrm{a}$ & $100.8 \pm 1.7 \mathrm{c}$ \\
Free fatty acids & $103.9 \pm 9.7 \mathrm{c}$ & $138.6 \pm 11.0 \mathrm{~b}$ & $198.7 \pm 6.8 \mathrm{a}$ & $139.8 \pm 6.6 \mathrm{~b}$ & $107.6 \pm 6.9 \mathrm{c}$ \\
$\alpha$-Tocopherol & $266.3 \pm 34.1 \mathrm{a}$ & $113.9 \pm 5.0 \mathrm{~b}$ & $259.2 \pm 9.0 \mathrm{a}$ & $410.6 \pm 107.2 \mathrm{a}$ & $291.0 \pm 0.1 \mathrm{a}$ \\
$\beta$-Tocopherol & $\mathrm{nd}^{* *}$ & $\mathrm{nd}$ & $\mathrm{nd}$ & $\mathrm{nd}$ & $\mathrm{nd}$ \\
$\gamma$-Tocopherol & $13.6 \pm 19.2 \mathrm{a}$ & $\mathrm{nd}$ & $\mathrm{nd}$ & $\mathrm{nd}$ & $26.4 \pm 37.3 \mathrm{a}$ \\
$\delta$-Tocopherol & $267.6 \pm 101.2 \mathrm{~b}$ & $\mathrm{nd}$ & $\mathrm{nd}$ & $278.4 \pm 24.2 \mathrm{~b}$ & $1,916.2 \pm 200.5 \mathrm{a}$ \\
\hline
\end{tabular}

* Data expressed as average values of three replicates $(n=3) \pm$ standard deviations. In each row, average values followed by different letters (a-d) indicate significant $(p<0.05)$ differences. Content on phospholipids, sterols and free fatty acids are expressed as $g$ $\mathrm{kg}^{-1}$ lipids. Content on tocopherol compounds is expressed as $\mathrm{mg} \mathrm{kg}^{-1}$ dry alga.

**nd: not detected. 


\section{TABLE 4}

Fatty acids composition of different brown, red and green seaweeds collected from the west Algerian coast*

\begin{tabular}{|c|c|c|c|c|c|}
\hline \multirow{2}{*}{ Fatty acid } & \multicolumn{2}{|c|}{ Brown seaweed } & \multirow{2}{*}{$\begin{array}{l}\text { Red seaweed } \\
\text { C. elongata }\end{array}$} & \multicolumn{2}{|c|}{ Green seaweed } \\
\hline & C. compressa & C. stricta & & E. compressa & U. lactuca \\
\hline Myristicacid (C14:0) & $6.11 \pm 0.62 b$ & $7.49 \pm 0.02 \mathrm{a}$ & $4.70 \pm 0.09 \mathrm{c}$ & $1.01 \pm 0.05 \mathrm{~d}$ & $1.07 \pm 0.02 \mathrm{~d}$ \\
\hline Pentadecylicacid (C15:0) & $1.10 \pm 0.17 \mathrm{bc}$ & $1.38 \pm 0.01 \mathrm{ab}$ & $1.68 \pm 0.02 \mathrm{a}$ & $1.10 \pm 0.02 \mathrm{bc}$ & $0.79 \pm 0.04 \mathrm{c}$ \\
\hline Palmiticacid (C16:0) & $48.34 \pm 0.67 \mathrm{~b}$ & $28.70 \pm 0.74 \mathrm{e}$ & $40.17 \pm 0.16 \mathrm{~d}$ & $50.48 \pm 0.42 \mathrm{a}$ & $44.93 \pm 0.07 \mathrm{c}$ \\
\hline Margaricacid (C17:0) & $1.33 \pm 0.08 \mathrm{a}$ & $1.57 \pm 0.05 \mathrm{a}$ & $0.88 \pm 0.08 \mathrm{~b}$ & $0.42 \pm 0.15 \mathrm{c}$ & $0.32 \pm 0.02 \mathrm{c}$ \\
\hline Stearicacid (C18:0) & $2.53 \pm 0.00 \mathrm{~b}$ & $5.52 \pm 0.11 \mathrm{a}$ & $2.21 \pm 0.08 \mathrm{~b}$ & $1.19 \pm 0.13 \mathrm{c}$ & $1.37 \pm 0.02 \mathrm{c}$ \\
\hline Palmitoleicacid (C16:1n-7) & $6.66 \pm 0.11 \mathrm{~b}$ & $8.26 \pm 0.23 \mathrm{a}$ & $3.05 \pm 0.07 \mathrm{c}$ & $2.14 \pm 0.01 \mathrm{~d}$ & $3.08 \pm 0.07 \mathrm{c}$ \\
\hline Vaccenicacid (C18:1n-7) & $5.59 \pm 0.03 \mathrm{~d}$ & $6.26 \pm 0.14 \mathrm{c}$ & $3.45 \pm 0.06 \mathrm{e}$ & $23.05 \pm 0.08 \mathrm{~b}$ & $29.02 \pm 0.16 \mathrm{a}$ \\
\hline Oleicacid (C18:1n-9) & $7.69 \pm 0.25 b$ & $9.39 \pm 0.12 \mathrm{a}$ & $7.40 \pm 0.12 b$ & $2.08 \pm 0.10 \mathrm{~d}$ & $4.79 \pm 0.01 \mathrm{c}$ \\
\hline Eicosenoic acid (C20:1n-9) & $0.18 \pm 0.25 \mathrm{c}$ & $0.98 \pm 0.06 \mathrm{ab}$ & $1.26 \pm 0.13 \mathrm{a}$ & $0.25 \pm 0.00 \mathrm{bc}$ & $0.22 \pm 0.31 \mathrm{c}$ \\
\hline Cetoleicacid (C22:1n-11) & $0.69 \pm 0.65 \mathrm{a}$ & $1.18 \pm 0.42 \mathrm{a}$ & $2.11 \pm 0.64 \mathrm{a}$ & $0.51 \pm 0.55 \mathrm{a}$ & $\mathrm{nd}^{* *}$ \\
\hline Nervonicacid (C24:1n-9) & $0.15 \pm 0.22 b$ & $3.25 \pm 0.02 \mathrm{a}$ & $0.78 \pm 0.06 b$ & $0.28 \pm 0.39 b$ & $0.38 \pm 0.41 \mathrm{~b}$ \\
\hline Linoleicacid (C18:2n-6) & $4.66 \pm 0.15 b$ & $3.47 \pm 0.18 \mathrm{c}$ & $2.35 \pm 0.09 \mathrm{~d}$ & $8.69 \pm 0.01 \mathrm{a}$ & $5.12 \pm 0.10 \mathrm{~b}$ \\
\hline Eicosadienoicacid (C20:2n-6) & $0.60 \pm 0.21 \mathrm{ab}$ & $1.12 \pm 0.32 \mathrm{a}$ & $1.09 \pm 0.04 \mathrm{a}$ & $0.10 \pm 0.15 b$ & nd \\
\hline Arachidonic acid (C20:4n-6) & $8.72 \pm 0.65 b$ & $12.60 \pm 0.00 \mathrm{a}$ & $11.95 \pm 0.14 \mathrm{a}$ & $3.58 \pm 0.02 \mathrm{c}$ & $1.35 \pm 0.10 \mathrm{~d}$ \\
\hline Eicosapentaenoic acid (C20:5n-3) & $3.62 \pm 0.04 \mathrm{c}$ & $6.37 \pm 0.03 \mathrm{~b}$ & $15.82 \pm 0.16 \mathrm{a}$ & $1.63 \pm 0.15 \mathrm{~d}$ & $1.59 \pm 0.12 \mathrm{~d}$ \\
\hline Docosatetraenoicacid (C22:4n-6) & $0.86 \pm 0.33 b$ & $0.51 \pm 0.24 \mathrm{~b}$ & $0.33 \pm 0.10 \mathrm{~b}$ & $1.76 \pm 0.08 \mathrm{a}$ & $0.41 \pm 0.01 \mathrm{~b}$ \\
\hline Docosapentaenoic acid (C22:5n-3) & $0.17 \pm 0.23 \mathrm{c}$ & $0.62 \pm 0.28 \mathrm{bc}$ & $0.19 \pm 0.26 \mathrm{c}$ & $1.36 \pm 0.05 \mathrm{~b}$ & $5.39 \pm 0.22 \mathrm{a}$ \\
\hline Docosahexaenoicacid (C22:6n-3) & $0.99 \pm 0.02 \mathrm{ab}$ & $1.33 \pm 0.01 \mathrm{a}$ & $0.60 \pm 0.10 \mathrm{bc}$ & $0.37 \pm 0.01 \mathrm{~cd}$ & $0.15 \pm 0.21 \mathrm{~d}$ \\
\hline
\end{tabular}

* Data expressed as average values of three replicates $(n=3) \pm$ standard deviations. In each row, average values followed by different letters $(a-e)$ indicate significant $(p<0.05)$ differences. Fatty acids content is expressed $\mathrm{g} / 100 \mathrm{~g}$ total fatty acids.

**nd: not detected. 


\section{TABLE 5}

\section{Contents* on macroelements and trace elements of different brown, red and green seaweeds collected from the west Algerian coast}

\begin{tabular}{|c|c|c|c|c|c|}
\hline & \multicolumn{2}{|c|}{ Brown seaweed } & \multirow{2}{*}{$\begin{array}{c}\text { Red seaweed } \\
\text { C. elongata }\end{array}$} & \multicolumn{2}{|c|}{ Green seaweed } \\
\hline & C. compressa & C. stricta & & E. compressa & U. lactuca \\
\hline \multicolumn{6}{|c|}{ MACROELEMENTS } \\
\hline $\mathrm{Ca}$ & $12.5 \pm 0.3 \mathrm{c}$ & $12.0 \pm 0.0 \mathrm{c}$ & $254.6 \pm 5.0 \mathrm{a}$ & $27.2 \pm 0.9 \mathrm{~b}$ & $14.0 \pm 0.3 \mathrm{c}$ \\
\hline $\mathrm{Mg}$ & $16.1 \pm 0.4 \mathrm{c}$ & $6.5 \pm 0.0 \mathrm{~d}$ & $30.5 \pm 0.7 \mathrm{~b}$ & $40.3 \pm 1.2 \mathrm{a}$ & $30.5 \pm 0.2 \mathrm{~b}$ \\
\hline K & $79.4 \pm 2.0 \mathrm{a}$ & $47.1 \pm 0.1 \mathrm{~b}$ & $6.1 \pm 0.1 \mathrm{e}$ & $10.8 \pm 0.4 \mathrm{~d}$ & $22.5 \pm 0.1 \mathrm{c}$ \\
\hline $\mathrm{Na}$ & $18.4 \pm 0.4 \mathrm{~b}$ & $19.5 \pm 0.0 \mathrm{a}$ & $2.6 \pm 0.0 \mathrm{c}$ & $3.7 \pm 0.0 \mathrm{~d}$ & $15.6 \pm 0.1 \mathrm{c}$ \\
\hline $\mathrm{Na} / \mathrm{K}$ ratio & $0.23 \pm 0.03 \mathrm{~d}$ & $0.41 \pm 0.01 \mathrm{~b}$ & $0.42 \pm 0.01 \mathrm{~b}$ & $0.34 \pm 0.02 \mathrm{c}$ & $0.69 \pm 0.01 \mathrm{a}$ \\
\hline Ion quotient ratio & $0.41 \pm 0.03 \mathrm{~d}$ & $0.77 \pm 0.04 \mathrm{~b}$ & $4.54 \pm 0.09 \mathrm{a}$ & $0.43 \pm 0.03 \mathrm{~d}$ & $0.55 \pm 0.05 \mathrm{c}$ \\
\hline \multicolumn{6}{|c|}{ TRACE ELEMENTS } \\
\hline As & $141.0 \pm 1.0 \mathrm{a}$ & $136.0 \pm 1.0 \mathrm{~b}$ & $7.4 \pm 0.7 \mathrm{c}$ & $4.4 \pm 0.6 \mathrm{c}$ & $6.2 \pm 0.1 \mathrm{c}$ \\
\hline B & $132.0 \pm 2.0 \mathrm{a}$ & $100.0 \pm 1.0 \mathrm{c}$ & $60.5 \pm 0.2 \mathrm{~d}$ & $47.8 \pm 1.8 \mathrm{e}$ & $104.0 \pm 1.0 \mathrm{~b}$ \\
\hline $\mathrm{Ba}$ & $9.8 \pm 0.1 \mathrm{a}$ & $10.0 \pm 0.0 \mathrm{a}$ & $5.7 \pm 0.0 \mathrm{c}$ & $6.1 \pm 0.0 \mathrm{~b}$ & $2.8 \pm 0.0 \mathrm{~d}$ \\
\hline $\mathrm{Cd}$ & $4.1 \pm 0.0 \mathrm{a}$ & $3.0 \pm 0.0 \mathrm{~b}$ & $<0.3 \mathrm{c}$ & $<0.3 \mathrm{c}$ & $<0.3 \mathrm{c}$ \\
\hline Co & $0.2 \pm 0.0 \mathrm{~b}$ & $<0.2 \mathrm{~b}$ & $0.3 \pm 0.0 \mathrm{a}$ & $<0.2 \mathrm{~b}$ & $<0.2 \mathrm{~b}$ \\
\hline $\mathrm{Cr}$ & $<0.4 \mathrm{e}$ & $0.6 \pm 0.0 \mathrm{~d}$ & $1.4 \pm 0.0 \mathrm{c}$ & $2.0 \pm 0.0 \mathrm{~b}$ & $3.0 \pm 0.1 \mathrm{a}$ \\
\hline $\mathrm{Cu}$ & $0.5 \pm 0.0 \mathrm{~d}$ & $0.8 \pm 0.0 \mathrm{c}$ & $<0.3 \mathrm{e}$ & $2.6 \pm 0.1 \mathrm{~b}$ & $2.0 \pm 0.0 \mathrm{a}$ \\
\hline $\mathrm{Fe}$ & $65.1 \pm 0.6 \mathrm{~d}$ & $133.0 \pm 1.0 \mathrm{c}$ & $228.0 \pm 1.0 \mathrm{a}$ & $230.0 \pm 10.0 \mathrm{a}$ & $189.0 \pm 1.0 \mathrm{~b}$ \\
\hline $\mathrm{Pb}$ & $0.4 \pm 0.0 \mathrm{~b}$ & $0.5 \pm 0.1 \mathrm{~b}$ & $1.2 \pm 0.1 \mathrm{a}$ & $<0.4 \mathrm{~b}$ & $<0.4 \mathrm{~b}$ \\
\hline $\mathrm{Li}$ & $0.3 \pm 0.0 \mathrm{~d}$ & $0.3 \pm 0.0 \mathrm{c}$ & $1.4 \pm 0.0 \mathrm{a}$ & $0.4 \pm 0.0 \mathrm{~b}$ & $0.4 \pm 0.0 \mathrm{~b}$ \\
\hline Mn & $3.6 \pm 0.0 \mathrm{e}$ & $8.1 \pm 0.1 \mathrm{a}$ & $12.5 \pm 0.0 \mathrm{~b}$ & $8.1 \pm 0.3 \mathrm{~d}$ & $8.6 \pm 0.0 \mathrm{c}$ \\
\hline $\mathrm{Hg}$ & $0.02 \pm 0.00 \mathrm{a}$ & $0.01 \pm 0.00 \mathrm{~b}$ & $0.01 \pm 0.00 \mathrm{~b}$ & $0.009 \pm 0.00 \mathrm{c}$ & $0.01 \pm 0.00 \mathrm{~b}$ \\
\hline $\mathrm{Ni}$ & $2.3 \pm 0.0 \mathrm{~b}$ & $1.4 \pm 0.0 \mathrm{~d}$ & $1.2 \pm 0.0 \mathrm{e}$ & $2.0 \pm 0.0 \mathrm{c}$ & $2.7 \pm 0.0 \mathrm{a}$ \\
\hline $\mathrm{Rb}$ & $49.0 \pm 0.7 \mathrm{a}$ & $32.9 \pm 0.3 \mathrm{~b}$ & $<1.6 \mathrm{e}$ & $6.6 \pm 0.1 \mathrm{~d}$ & $10.7 \pm 0.4 \mathrm{c}$ \\
\hline $\mathrm{Se}$ & $<0.04 \mathrm{a}$ & $<0.04 \mathrm{a}$ & $<0.04 \mathrm{a}$ & $<0.04 \mathrm{a}$ & $<0.04 \mathrm{a}$ \\
\hline $\mathrm{Sr}$ & $1102.0 \pm 26.0 \mathrm{~b}$ & $1076.0 \pm 3.0 \mathrm{~b}$ & $1455.0 \pm 34.0 \mathrm{a}$ & $272.0 \pm 6.0 \mathrm{c}$ & $133.0 \pm 3.0 \mathrm{~d}$ \\
\hline $\mathrm{V}$ & $<0.7 \mathrm{~d}$ & $<0.7 \mathrm{~d}$ & $2.1 \pm 0.0 \mathrm{c}$ & $18.0 \pm 0.9 \mathrm{a}$ & $7.6 \pm 0.1 \mathrm{~b}$ \\
\hline $\mathrm{Zn}$ & $10.5 \pm 0.0 \mathrm{~b}$ & $10.2 \pm 0.0 \mathrm{c}$ & $21.6 \pm 0.1 \mathrm{a}$ & $5.5 \pm 0.0 \mathrm{e}$ & $7.8 \pm 0.0 \mathrm{~d}$ \\
\hline
\end{tabular}

* Data expressed as average values of three replicates $(n=3) \pm$ standard deviations. In each row, average values followed by different letters $(\mathrm{a}-\mathrm{e})$ indicate significant $(p<0.05)$ differences. Macroelements values are expressed as $\mathrm{g} \mathrm{kg}^{-1}$ dry alga; trace elements values are expressed as $\mathrm{mg} \mathrm{kg} \mathrm{kg}^{-1}$ dry alga. 
TABLE 6

Estimated and acceptable daily intakes* of macroelements and trace elements of seaweeds collected from the west Algerian coast

\begin{tabular}{|c|c|c|c|c|c|c|}
\hline \multirow[t]{2}{*}{ Element } & \multicolumn{2}{|c|}{ Brown seaweed } & \multirow{2}{*}{$\begin{array}{c}\text { Red seaweed } \\
\text { C. elongata }\end{array}$} & \multicolumn{2}{|c|}{ Green seaweed } & \multirow{2}{*}{$\begin{array}{c}\text { Reference } \\
\text { values }\end{array}$} \\
\hline & C. compressa & C. stricta & & E. compressa & U. lactuca & \\
\hline \multicolumn{7}{|l|}{$\begin{array}{l}\text { Macro- } \\
\text { elements }\end{array}$} \\
\hline $\mathrm{Ca}$ & 40.53 & 38.91 & 825.63 & 88.20 & 45.40 & 1,000 \\
\hline $\mathrm{Mg}$ & 52.21 & 21.07 & 98.90 & 130.68 & 98.90 & $320-420$ \\
\hline $\mathrm{K}$ & 257.48 & 152.73 & 19.78 & 35.02 & 72.96 & 4,700 \\
\hline $\mathrm{Na}$ & 59.66 & 63.23 & 8.43 & 11.99 & 50.58 & 1,500 \\
\hline \multicolumn{7}{|l|}{$\begin{array}{l}\text { Trace } \\
\text { elements }\end{array}$} \\
\hline As & $4.57 \mathrm{E}-01$ & $4.41 \mathrm{E}-01$ & 2.39E-02 & $1.42 \mathrm{E}-02$ & $2.01 \mathrm{E}-02$ & $\mathrm{nd}^{* *}$ \\
\hline B & 4.28E-01 & 3.24E-01 & $1.96 \mathrm{E}-01$ & $1.55 \mathrm{E}-01$ & 3.37E-01 & 20 \\
\hline $\mathrm{Ba}$ & $3.17 \mathrm{E}-02$ & $3.24 \mathrm{E}-02$ & $1.84 \mathrm{E}-02$ & 1.97E-02 & $9.08 \mathrm{E}-03$ & $\mathrm{nd}^{* *}$ \\
\hline $\mathrm{Cd}$ & $1.32 \mathrm{E}-02$ & $9.72 \mathrm{E}-03$ & $<9.72 \mathrm{E}-04$ & $<9.72 \mathrm{E}-04$ & $<9.72 \mathrm{E}-04$ & $1.00 \mathrm{E}-03$ \\
\hline Co & $6.48 \mathrm{E}-04$ & $<6.48 \mathrm{E}-04$ & $9.72 \mathrm{E}-04$ & $<6.48 \mathrm{E}-04$ & $<6.48 \mathrm{E}-04$ & $\mathrm{nd}^{* *}$ \\
\hline $\mathrm{Cr}$ & $1.29 \mathrm{E}-03$ & $1.94 \mathrm{E}-03$ & $4.54 \mathrm{E}-03$ & $6.48 \mathrm{E}-03$ & $9.72 \mathrm{E}-03$ & $(2.5-3.5) \mathrm{E}-02$ \\
\hline $\mathrm{Cu}$ & $1.62 \mathrm{E}-03$ & $2.59 \mathrm{E}-03$ & $9.72 \mathrm{E}-04$ & $8.43 \mathrm{E}-03$ & $6.48 \mathrm{E}-03$ & 0.9 \\
\hline $\mathrm{Fe}$ & $2.11 \mathrm{E}-01$ & $4.31 \mathrm{E}-01$ & 7.39E-01 & $7.45 \mathrm{E}-01$ & $6.12 \mathrm{E}-01$ & $8-18$ \\
\hline $\mathrm{Pb}$ & $1.29 \mathrm{E}-03$ & $1.62 \mathrm{E}-03$ & $3.89 \mathrm{E}-03$ & $<1.29 \mathrm{E}-03$ & $<1.29 \mathrm{E}-03$ & $3.57 \mathrm{E}-03$ \\
\hline $\mathrm{Li}$ & $9.72 \mathrm{E}-04$ & $9.72 \mathrm{E}-04$ & $4.54 \mathrm{E}-03$ & $1.29 \mathrm{E}-03$ & $1.29 \mathrm{E}-03$ & $0.65-3.10$ \\
\hline $\mathrm{Mn}$ & $1.16 \mathrm{E}-02$ & $2.62 \mathrm{E}-02$ & 4.05E-02 & $2.62 \mathrm{E}-02$ & $2.78 \mathrm{E}-02$ & $1.8-2.3$ \\
\hline $\mathrm{Hg}$ & $6.48 \mathrm{E}-05$ & $3.24 \mathrm{E}-05$ & 3.24E-05 & 2.91E-05 & $3.24 \mathrm{E}-05$ & 5.71E-04 \\
\hline $\mathrm{Ni}$ & $7.45 \mathrm{E}-03$ & $4.54 \mathrm{E}-03$ & $3.89 \mathrm{E}-03$ & $6.48 \mathrm{E}-03$ & $8.75 \mathrm{E}-03$ & 1 \\
\hline $\mathrm{Rb}$ & $1.58 \mathrm{E}-01$ & $1.06 \mathrm{E}-01$ & $<5.18 \mathrm{E}-03$ & $2.14 \mathrm{E}-02$ & $3.46 \mathrm{E}-02$ & $\mathrm{nd}^{* *}$ \\
\hline $\mathrm{Se}$ & $<1.29 \mathrm{E}-04$ & $<1.29 \mathrm{E}-04$ & $<1.29 \mathrm{E}-04$ & $<1.29 \mathrm{E}-04$ & $<1.29 \mathrm{E}-04$ & $5.5 \mathrm{E}-02$ \\
\hline $\mathrm{Sr}$ & 3.57 & 3.48 & 4.71 & $8.82 \mathrm{E}-01$ & $4.31 \mathrm{E}-01$ & $\mathrm{nd}^{* *}$ \\
\hline $\mathrm{V}$ & $<2.27 \mathrm{E}-03$ & $<2.27 \mathrm{E}-03$ & $6.81 \mathrm{E}-03$ & $5.83 \mathrm{E}-02$ & $2.46 \mathrm{E}-02$ & 1.8 \\
\hline $\mathrm{Zn}$ & $3.40 \mathrm{E}-02$ & $3.30 \mathrm{E}-02$ & $7.00 \mathrm{E}-02$ & $1.78 \mathrm{E}-02$ & $2.52 \mathrm{E}-02$ & $8-11$ \\
\hline
\end{tabular}

* Estimated daily intakes and reference values are expressed as $\mathrm{mg}$ dry alga $\mathrm{kg}^{-1}$ day $^{-1}$ for adult female and male (19-70 years, body weight $70 \mathrm{~kg}$ ).

** nd: Not determined. 


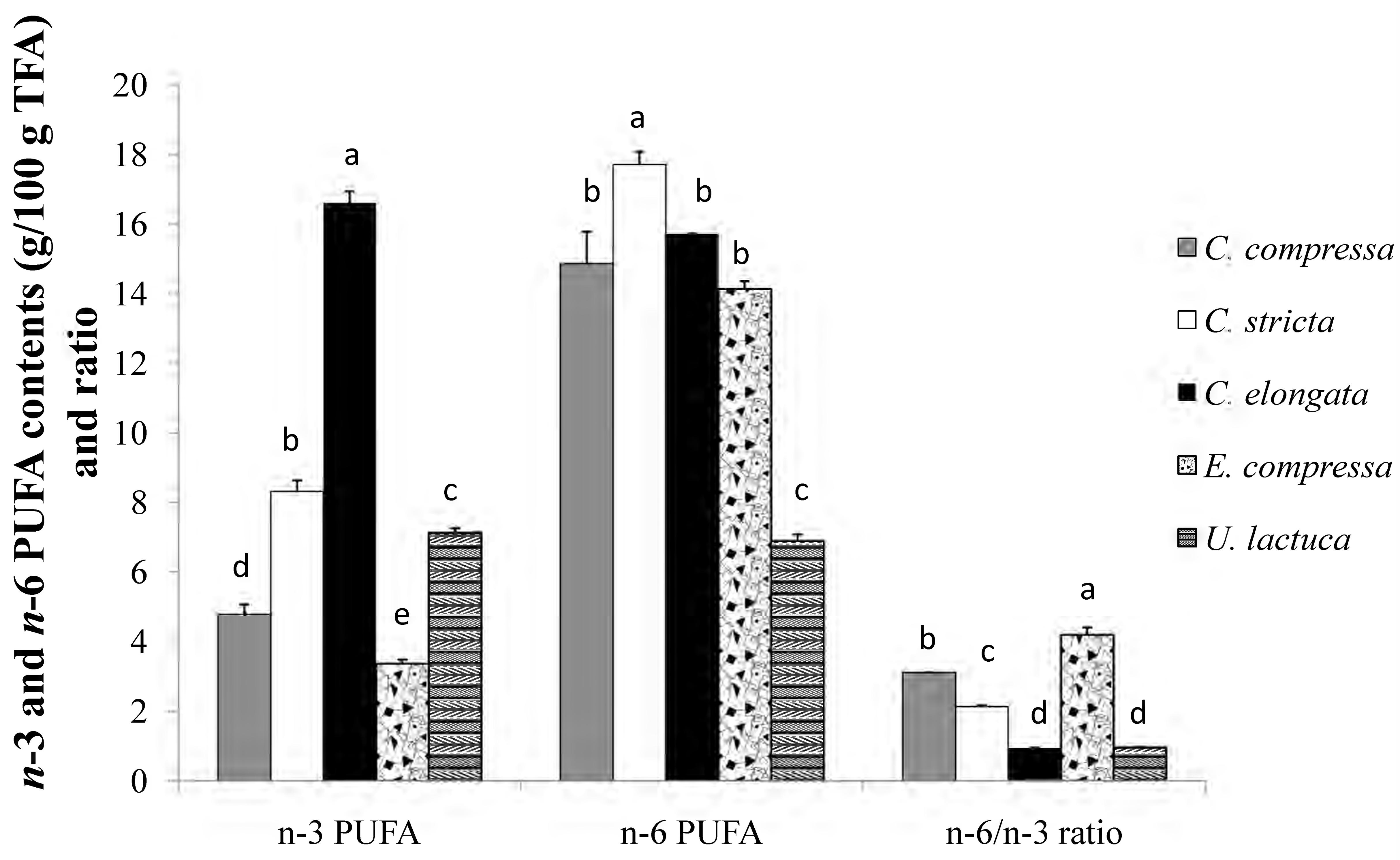




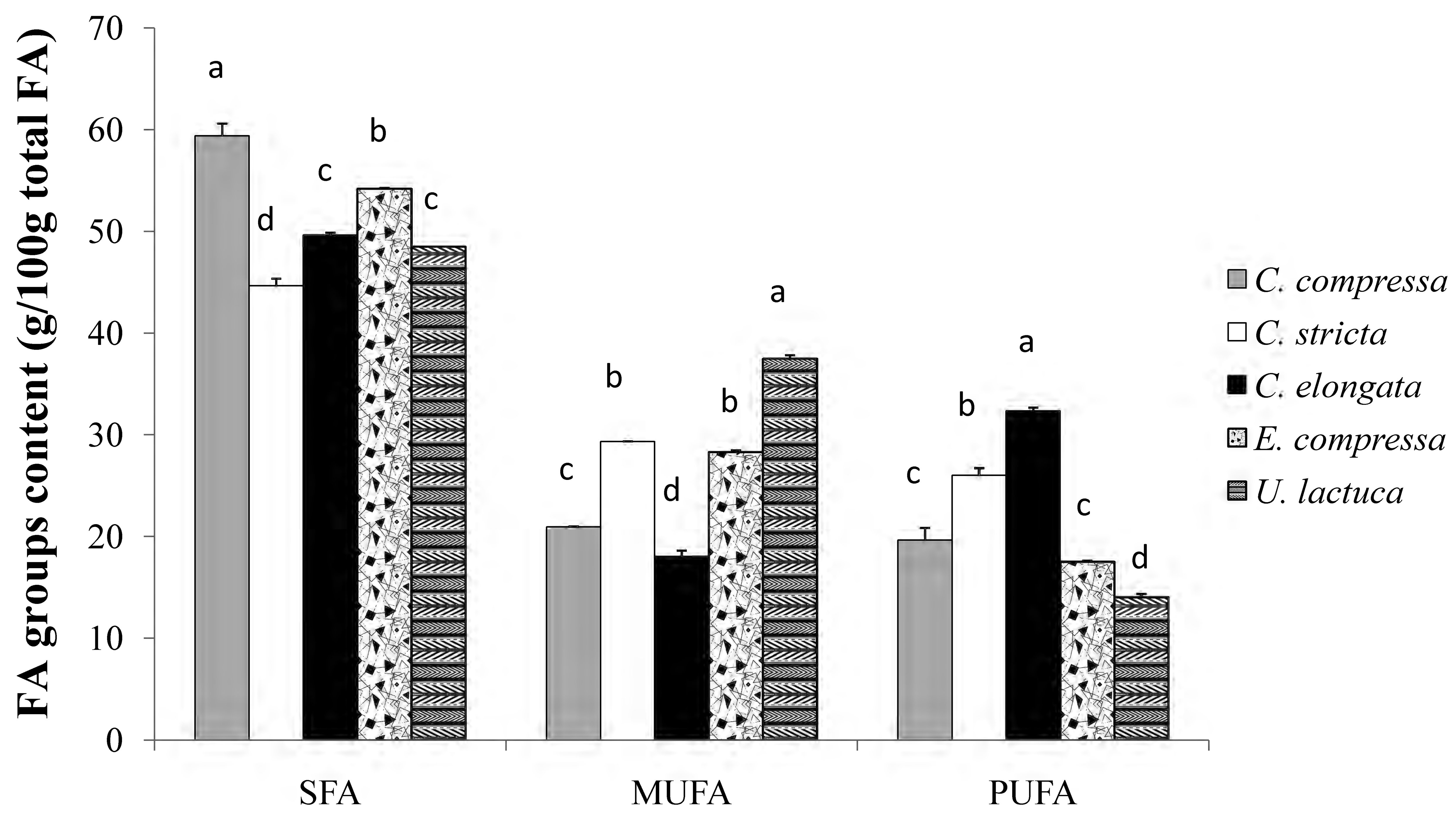

